\title{
PERBEDAAN BERKUMUR MENGGUNAKAN AIR REBUSAN DAUN SIRIH DENGAN FORMULA PROTECTOR CITRUS MINT TERHADAP PENURUNAN INDEKS PLAK PADA SISWA/I KELAS IV SD NEGERI NO. 066428 MEDAN TUNTUNGAN
}

\author{
Sri Junita Nainggolan, Asnita Bungaria Simaremare \\ Jurusan Keperawatan Gigi Poltekkes Kemenkes Medan
}

\begin{abstract}
Abstrak
Sirih merupakan tumbuhan obat yang mengandung zat antiseptik pada seluruh bagiannya, dan termasuk dalam kelompok obat kesehatan gigi dan mulut. Obat kumur formula protector citrus mint bebas alkohol dan mampu membunuh kuman penyebab bau mulut. Jenis penelitian ini adalah penelitian analitik menggunakan eksperimen semu dengan rancangan pre-test dan post- test kontrol group desain dengan memakai air putih sebagai kelompok kontrol dan menggunakan uji t-Test. Penelitian ini menggunakan replikasi sebanyak tiga kali.. Sampel penelitian berjumlah 45 siswa.. Penelitian ini bertujuan untuk mengetahui perbandingan berkumur dengan air rebusan daun sirih dan formula protector citrus mint terhadap penurunan indeks plak. Hasil penelitian ini menunjukkan indeks plak rata-rata sebelum berkumur dengan air putih, air rebusan daun sirih dan formula protector citrus mint $100 \%$ menunjukkan kriteria indeks plak buruk dan indeks plak sesudah berkumur dengan, indeks plak sesudah berkumur air rebusan daun sirih yaitu 66,7 dengan kriteria baik dan 33,3 \% dengan kriteria sedang, indeks plak sesudah berkumur dengan formula protector citrus mint yaitu 100\% sedangkan indeks plak sesudah berkumur air putih yaitu 6,7 \% dengan kriteria baik, 93,3 \% dengan kriteria sedang dengan kriteria baik. Kesimpulan uji t-Test dependent yaitu ada pengaruh antara berkumur air putih, air rebusan daun sirih dan formula protector citrus mint terhadap penurunan indeks plak, sedangkan uji t-Test Independent yaitu berkumur dengan formula protector citrus mint lebih efektif untuk menurunkan indeks plak dibandingkan dengan air putih dan air rebusan daun sirih.
\end{abstract}

Kata kunci : Air Rebusan Daun Sirih, Formula Protector Citrus Mint, Indeks Plak

\section{PENDAHULUAN}

Kesehatan gigi dan mulut merupakan bagian dari kesehatan umum yang berperan panting dalam fungsi pengunyahan, fungsi berbicara dan fungsi kecarrtikan. Ketiga fungsi tersebut sangat berperan penting dalam menjunjung perkembangan anak (Depkes Rl, 1996).

Hasil Riset Kesehatan Dasar Nasional (Riskesdas) tahun 2007 menyebutkan bahwa 23,4\% penduduk Indonesia mempunyai masalah kesehatan gigi dan mulut dan hanya 29,6\% penduduk yang menerima perawatan dan pengobatan dari tenaga kesehatan gigi. Hal ini mengindikasikan bahwa masih terdapat masyarakat yang belum menyadari pentingnya pemeliharaan kesehatan gigi dan mulut.

Penyakit karies gigi dan jaringan pendukung gigi (periodontal) umumnya disebabkan oleh plak gigi, yang sampai saat ini masih menjadi masalah utema dalam bidang kesehatan gigi dan mulut. Plak gigi adalah lendir yang lengket yang berisi bakteri dan produk-produknya yang terbentuk pada permukaan gigi (Kidd dan Bechal, 1992).

Obat kumur menurut Farmakope Indonesia III adalah sediaan berupa larutan yang umumnya pekat yang harus diencerkan teriebih dahulu sebelum digunakan, dimaksudkan untuk digunakan sebagai pencegahan atau pengobatan infeksi tenggorokan.

Sirih adalah jenis tanaman yang banyak tumbuh dan dijumpai di daerah tropis seperti Indonesia. Beberapa literature menyebutkan bahwa daun sirih memiliki sifat menahan perdarahan, menyembuhkan luka, menguatkan gigi dan membersihkan tenggorokan. Minyak atsiri daun sirih diketahui memiliki daya antibakteri, hal ini disebabkan oleh karena adanya senyawa fenol dan turunannya yang dapat mengubah sifat protein sel bakteri (Jenie BS, 2007). Senyawa fenol tersebut antara lain katekin dan tannin. Dalam mencegah pembentukan plak gigi, katekin bekerja dengan cara mendenaturasi protein dari bakteri (Agustin DW, 2008 ).

Pada survei awal yang dilakukan pada siswa/i kelas IV SD Negeri No.066428 Medan Tuntungan, peneliti melihat bahwa banyak siswa/i yang mempunyai kriteria indeks plak walaupun di SD tersebut sudah pernah dilakukan penyuluhan dan pelayanan kesehatan gigi dan mulut dari puskesmas setempat. Berdasarkan uraian diatas maka peneliti ingin mengetahui tentang perbedaan berkumur menggunakan air rebusan daun sirih dengan formula protector citrus mint terhadap penurunan indeks plak pada siswa/i kelas IV SD Negeri No.066428 Medan Tuntungan iahun 2013. 


\section{RUMUSAN MASALAH}

Rumusan masalah dalam penelitian ini adalah bagaimana perbedaan berkumur menggunakan air rebusan daun sirih dengan formula protector citrus mint terhadap penurunan indeks plak pada siswa/i kelas IV SD Negeri No.066428 Medan Tuntungan.

\section{TUJUAN PENELITIAN}

\section{Tujuan Umum}

Penelitian ini bertujuan untuk mengetahui perbedaan berkumur menggunakan air rebusan daun sirih dengan formula protector citrus mint terhadap penurunan indeks plak pada siswa/i kelas IV SD Negeri No.066428 Medan Tuntungan

\section{Tujuan Khusus}

1. Untuk mengetahui skor indeks plak rata-rata pada siswa/i kelas IV SD Negeri No.066428 Medan Tuntungan sebelum dan sesudah berkumur air rebusan daun sirih

2. Untuk mengetahui skor indeks plak rata-rata pada siswa/i kelas IV SD Negeri No.066428 Medan Tuntungan sebelum dan sesudah berkumur dengan formula protector citrus mint.

3. Untuk mengetahui persentase kriteria indeks plak pada siswa/i kelas IV SD Negeri No.066428 Medan Tuntungan sebelum dan sesudah berkumur dengan air rebusan daun sirih.

4. Untuk mengetahui persentase kriteria indeks plak pada siswa/i kelas IV SD Negeri No.066428 Medan Tuntungan sebelum dan sesudah berkumur dengan formula protector citrus mint.

\section{Manfaat Penelitian}

1. Hasil penelitian ini diharapkan dapat menambah wawasan dan ilmu pengetahuan bagi siswa/i kelas IV SD Negeri No.066428 Medan Tuntungan untuk menjaga kebersihan gigi dan mulutnya.

2. Hasil penelitian ini diharapkan dapat berguna sebagai bahan informasi untuk penelitian selanjulnya.

\section{METODE PENELITIAN}

\section{Jenis dan Desain Penelitian}

Metode penelitian yang digunakan adalah Quasi Eksperiment atau sering disebut eksperimen semu yaitu suatu penelitian dengan adanya suatu perlakuan terhadap kelompok sampel dengan menggunakan kelompok kontrol (semua kelompok sampel mendapatkan perlakuan). Rancangan dalam penelitian ini menggunakan rancangan waktu ( time design series )/ rancangan pre-test dan posttest kontrol group design. Didalam penelitian ini dilakukan replikasi sebanyak tiga kali untuk melakukan kegiatan berkumur dengan menggunakan air putih, air rebusan daun sirih dan formula pprotector citrus mint pada hari yang berbeda unluk mengetahui perbedaan berkumur menggunakan air rebusan daun sirih dengan formula protector citrus mint terhadap penurunan indeks plak pada siswa/i kelas IV SD Negeri No.066428 Medan Tuntungan tahun 2013

\section{Lokasi dan Waktu Penelitian}

Lokasi penelitian ini adalah SD Negeri No.066428 Medan Tuntungan yang terletak di jalan Bekala Desa Sidomulyo kecamatan Medan Tuntungan. Peneliti tertarik untuk melakukan penelitian tentang kesehatan gigi dan mulut disekolah tersebut karena pada sekolah tersebut sudah pernah dilakukan pelayanan kesehatan gigi dan mulut akan tetapi terdapat indeks plak yang buruk pada siswa/i SD Negeri No.066428 Medan Tuntungan. Penelitian ini dilaksanakan mulai bulan Maret sampai dengan bulan Juli tahun 2013.

\section{Populasi dan Sampel Penelitian}

Populasi dalam penelitian ini adalah seluruh siswa/i kelas IV SD Negeri No.066428 Medan Tuntungan yaitu dengan jumlah populasi 185 orang.

\section{Sampel Penelitian}

Peneliti mengambil sampel penelitian dengan Teknik Random Sampling. Teknik Random Sampling adalah teknik pengambilan sampel dimana semua individu dalam populasi baik secara sendiri-sendiri atau bersamasama diberi kesempatan yang sama untuk dipilih menjadi anggota sampel ( Narbuko dan Abu Achmadi, 1991).

Sampel yang diambil oleh peneliti berjumlah 45 siswa yang selanjutnya 45 siswa dibagi menjadi 3 kelompok

> Kelompok I yaitu 15 siswa yang berkumur dengan air rebusan daun sirih

$>$ Kelompk II yaitu 15 siswa yang berkumur dengan formula protector citrus mint

> Kelompok 111 yaitu 15 siswa yang berkumur dengan airputih.

Lalu penelitian ini diulang sebanyak tiga kali dengan sampel yang sama pada hari yang berbeda. Persyaratan sampel:

$>$ Tidak menggunakan pesawat orthodontik

> Minimal harus ada 2 dari 6 gigi indeks

> Sampel jangan menyikat gigi pada pagi hari

\section{Jenis dan Cara Pengumpulan Data}

Jenis data yang digunakan adalah adalah data primer dan data sekunder. Data primer adalah data yang diperoleh secara langsung oleh peneliti yaitu data tentang indeks plak dengan teknik pemeriksaan langsung ke mulut siswa/i yang menjadi sampel. Data sekunder adalah data yang diperoleh dari instansi tertentu. Persiapan alat dan bahan sebagai berikut :

\section{Alat terdiri dari}

1. Sonde

2. Kaca mulut

3. Pinset

4. Excavator

5. Gelas kumur

6. Lembar pemeriksaan 
Bahan terdiri dari:
1. Masker
2. Hand schoen
3. Disclosing solution
4. Kapas
5. Desinfektan

Pelaksanaanya sebagai berikut :

1. Orang pertama (peneliti) memeriksa indeks plak siswa/i

2. Orang kedua memanggil satu persatu siswa/i dari 3 kelompok yang telah dibagi sebelumnya dan mencatat hasil pemeriksaan sebelum berkumur di lembar pemeriksaan.

3. Berkumur dilakukan selama 30 detik untuk tiap siswa. Lamanya waktu berkumur dihitung menggunakan stopwatch.

4. Hasil pemeriksaan indeks plak dari 45 siswa dicatat oleh orang kedua dalam lembar pemeriksaan.

5. Kegiatan berkumur dan pemeriksaan indeks plak berlangsung hingga tiga kali pengulangan pada hari yang berbeda dengan teknik pelaksanaan yang sama.

6. Lembar pemeriksaan yang telah diisi oleh orang kedua dikumpul dan dihitung.

7. Indeks plak siswa/i dihitung dimulai dengan indeks plak baik, sedang dan buruk.

8. Selanjutnya menghitung persentase indeks plak dan setelah baik sebelum berkumur dan sesudah berkumur dengan air rebusan daun sirih, formula protector citrus mint dan air putih.

9. Membandingkan hasil indeks plak yang diperoleh sebelum berkumur dan setelah berkumur dengan air rebusan daun sirih, formula protector citrus mint dan air putih.

10. Data dimasukkan dalam tabel.

\section{Pengolahan dan Analisa Data}

Setelah pengumpulan data maka dilakukan analisa data dengan tehnik sebagai berikut :

1. Editing ( pemeriksaan )

Editing adalah upaya untuk memeriksa kembali kebenaran data yang telah diperoleh. Dalam melakukan editing ada beberapa hal yang harus diperhatikan :
a. Memeriksa kelengkapan data
b. Memeriksa kesinambungan data
c. Memeriksa keseragaman data

2. Coding

Coding adalah pemberian kode numeric (angka) terhadap data yang terdiri atas beberapa kategori.

3. Tabulasi data

Tabulasi data dilakukan jika semua masalah dan coding telah selesai, sehingga data selanjutnya dimasukkan kedalam tabet.

\section{HASIL DAN PEMBAHASAN}

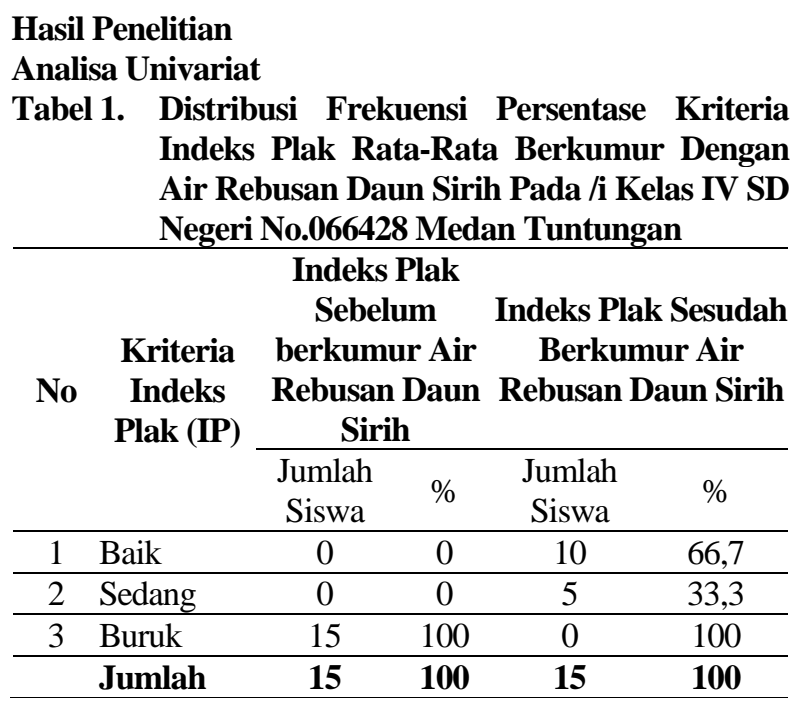

Dari Tabel 1 di atas terlihat bahwa indeks plak sebelum berkumur air rebusan daun sirih dari 15 siswa yang diperiksa dalam 3 kali pemeriksaan terdapat seluruh siswa mempunyai kriteria indeks plak buruk dengan persentase $100 \%$ dan tidak terdapat kriteria baik maupun sedang dan persentase indeks plak sesudah berkumur air rebusan daun sirih terdapat 10 siswa dengan kriteria indeks plak baik dengan persentase rata-rata indeks plak 66,7\% dan 5 siswa dengan kriteria indeks plak sedang dengan persentase rata-rata indeks plak 33,3\% serta tidak terdapat kriteria indeks plak buruk.

Tabel 2. Distribusi Frekuensi Persentase Kriteria Indeks Plak Rata-Rata Sebelum Berkumur Dengan Formula Protector Citrus Mint Pada /I Kelas IV SD Negeri No.066428 Medan Tuntungan

\begin{tabular}{cccccc}
\hline & & $\begin{array}{c}\text { Indeks Plak } \\
\text { Sebelum Berkumur } \\
\text { Dengan Formula } \\
\text { No }\end{array}$ & $\begin{array}{c}\text { Kriteria } \\
\text { Indeks } \\
\text { Plak (IP) }\end{array}$ & $\begin{array}{c}\text { Indeks Plak } \\
\text { Protector Citrus } \\
\text { Mint }\end{array}$ & $\begin{array}{c}\text { Sesudah } \\
\text { Berkumur } \\
\text { Dengan Formula } \\
\text { Protector Citrus } \\
\text { Mint }\end{array}$ \\
\cline { 2 - 6 } & & $\begin{array}{c}\text { Jumlah } \\
\text { Siswa }\end{array}$ & $\begin{array}{c}\text { \% } \\
\text { Jumlah } \\
\text { Siswa }\end{array}$ & $\%$ \\
\hline 1 & Baik & 0 & 0 & 10 & 66,7 \\
\hline 2 & Sedang & 0 & 0 & 5 & 33,3 \\
\hline 3 & Buruk & 15 & 100 & 0 & 100 \\
\hline & Jumlah & $\mathbf{1 5}$ & $\mathbf{1 0 0}$ & $\mathbf{1 5}$ & $\mathbf{1 0 0}$ \\
\hline
\end{tabular}

Dari Tabel 2 di atas terlihat bahwa indeks plak sebelum berkumur dengan formula protector citrus mint dari 15 siswa yang diperiksa dalam 3 kali pemeriksaan terdapat seluruh siswa mempunyai kriteria indeks plak buruk dengan persentase rata-rata indeks piak yaitu 100\% dan tidak terdapat kriteria baik maupun sedang dan persentase indeks plak dan sesudah berkumur formula protector citrus mint tidak terdapat siswa/l dengan kriteria indeks plak buruk dan sedang. Seluruh siswa/l 
menunjukkan kriteria indeks plak baik dengan persentase indeks plak rata-rata $100 \%$.

Tabel 3. Distribusi Frekuensi Persentase Kriteria Indeks Plak Rata-Rata Berkumur Dengan Air Putih Pada /I Kelas IV SD Negeri No.066428 Medan Tuntungan

\begin{tabular}{llcccc}
\hline & & $\begin{array}{c}\text { Indeks Plak } \\
\text { No }\end{array}$ & $\begin{array}{c}\text { Kriteria } \\
\text { Indeks } \\
\text { Plak (IP) }\end{array}$ & $\begin{array}{c}\text { Sebelum Berkumur } \\
\text { Dengan Air Putih }\end{array}$ & $\begin{array}{c}\text { Indeks Plak } \\
\text { Sesudah } \\
\text { Berkumur Dengan } \\
\text { Air Putih }\end{array}$ \\
\cline { 3 - 6 } & & Jumlah Siswa & $\%$ & $\begin{array}{c}\text { Jumlah } \\
\text { Siswa }\end{array}$ & $\%$ \\
\hline 1 & Baik & 0 & 0 & 1 & 6,7 \\
\hline 2 & Sedang & 0 & 0 & 14 & 93,3 \\
\hline 3 & Buruk & 15 & 100 & 0 & 0 \\
\hline & Jumlah & $\mathbf{1 5}$ & $\mathbf{1 0 0}$ & $\mathbf{1 5}$ & $\mathbf{1 0 0}$ \\
\hline
\end{tabular}

Dari Tabel 3. di atas terlihat bahwa persentase kriteria indeks plak sebelum berkumur air putih dari 15 siswa yang diperiksa dalam 3 kali pemeriksaan terdapat seluruh siswa mempunyai kriteria indeks plak buruk dengan persentase $100 \%$ dan tidak terdapat kriteria bark maupun sedang dan persentase kriteria indeks plak sesudah berkumur air putih terdapat 1 siswa dengan kriteria indeks plak baik dengan persentase 6,7 \% dan 14 siswa dengan kriteria indeks plak sedang dengan persentase 93,9 \% serta tidak terdapat kriteria indeks plak buruk.

\section{Analisa Bivariat}

Dependent t-Test

Tabel 4. Paired Samples Statistics Untuk Kelompok berkumur Dengan Air Rebusan Daun Sirih

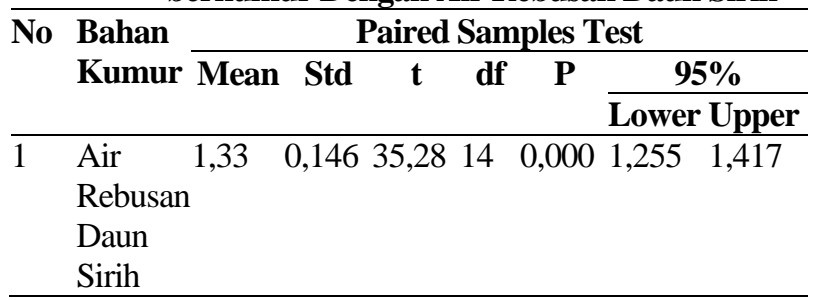

Berdasarkan nilai perbandingan sebelum dan sesudah berkumur dengan air rebusan daun sirih, dapat diketahui nilai rata-rata yaitu 1,33 dengan standar deviasi 0,146, nilai t yaitu 35,28 dan derajat kebebasan 14 . Berdasarkan hasil uji t-test dependent $\mathrm{p}<0,05$, jadi ada perbedaan antara sebelum dan sesudah berkumur dengan air putih. Ho ditolak.

Tabel 5. Paired Samples Statistics Untuk Kelompok berkumur Dengan Formula Protector Citrus Mint

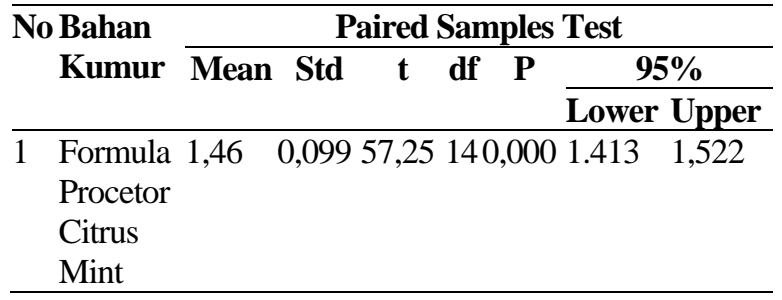

Berdasarkan nilai perbandingan sebelum dan sesudah berkumur dengan formula protector citrus mint, dapat diketahui nilai rata-rata yaitu 1,46, dengan standar deviasi 0,099, nilai t yaitu 57,25 dan derajat kebebasan yaitu 14 . Berdasarkan hasit uji t-test dependent $\mathrm{p}<0,05$, jadi ada perbedaan antara sebelum dan sesudah berkumur dengan air putih. Ho ditolak.

Tabel 6. Paired Samples Statistics Untuk Kelompok berkumur Oengan Air Putih

\begin{tabular}{|c|c|c|c|c|c|c|}
\hline \multirow[t]{3}{*}{ No } & \multirow{3}{*}{$\begin{array}{l}\text { Bhan } \\
\text { Kumur }\end{array}$} & \multicolumn{5}{|c|}{ Paired Samples Test } \\
\hline & & Mean Std & df & $\mathbf{P}$ & & $5 \%$ \\
\hline & & & & & Lowe & Upper \\
\hline 1 & $\begin{array}{l}\text { Air } \\
\text { putih }\end{array}$ & 0,09 & 51,1314 & 0,000 & 1,15 & 1,25 \\
\hline
\end{tabular}

Berdasarkan nilai perbandingan sebelum dan sesudah berkumur dengan air putih, dapat diketahui nilai rata-rata yaitu 1,20 , dengan standar deviasi 0,09 , nilai yaitu 51,13 serta derajat kebebasan yaitu 14. Berdasarkan hasil uji t-test dependent $\mathrm{p}<0,05$, jadi ada perbedaan antara sebelurn dan sesudah berkumur dengan air putih. Hoditolak.

\section{Independent t-Test}

Untuk mengetahui apakah ada perbedaan antara berkumur dengan menggunakan air putih, air rebusan daun sirih dan formula protector citrus mint terhadap penurunan indeks plak maka dilakukan t-Test independent. Adapun hasil t-Test independent yang dilakukan adalah sebagai berikut.

Tabel 7. Independent Sampel Tes berkumur Dengan Air Putih Dan Air Rebusan Daun Sirih

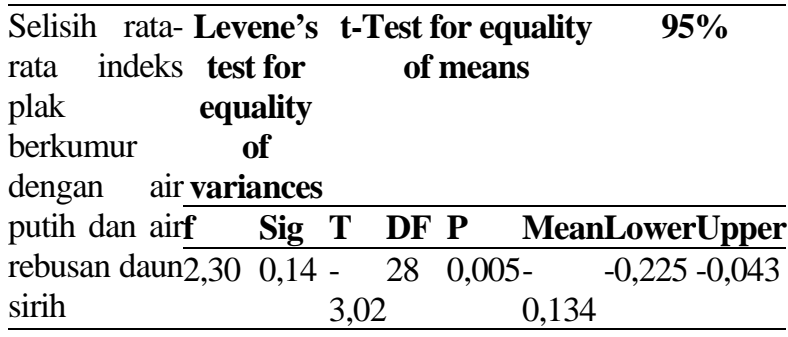

Dari tabel diatas diketahui bahwa hasil uji t-Test independent yang dilakukan berdasarkan Levene's Test for equality of variances diperoleh nilai $\mathrm{f}$ hrtung 2,30 dengan probabilitas 0,14 . Oleh karena $p<0,05$ yaitu 0,005 menunjukkan bahwa Ho ditolak. Sehingga dapat disimpulkan bahwa ada perbedaan antara berkumur dengan air putih dan formula protector citrus mint.

Tabel 8. Independent Sampel Tes berkumur Dengan Air Putih Dan Formula protector citrus mint

\begin{tabular}{|c|c|c|c|c|c|c|}
\hline $\begin{array}{l}\text { Selisih rata-rata } \\
\text { indeks plak } \\
\text { berkumur } \\
\text { dengan air putih }\end{array}$ & $\begin{array}{c}\text { Levene's } \\
\text { test for } \\
\text { equality of } \\
\text { variances }\end{array}$ & t-Test f & $\begin{array}{l}\text { or equ } \\
\text { means }\end{array}$ & ality of & & $5 \%$ \\
\hline dan formulaf & f $\quad$ Sig & DF & $\mathbf{P}$ & Mean & Lower & Upper \\
\hline $\begin{array}{l}\text { protector citrus } 1 \\
\text { mint }\end{array}$ & 0,26 & $-7,2714$ & 0,000 & $-0,26$ & $-0,333$ & $-0,186$ \\
\hline
\end{tabular}


Dari label diatas diketahui bahwa hasil uji t-Test independent yang dilakukan berdasarkan Levene's Test for equality of variances diperoleh nilai $\mathrm{f}$ hitung 1,30 dengan prababilitas 0,26 . Oleh karena $p<0,05$ yaitu 0,000 menunjukkan bahwa Ho ditolak. Sehingga dapat disimpulkan bahwa ada perbedaan antara berkumur dengan air putih dan formula protector citrus mint.

\section{Tabel A.1.15. Independent Sampel Tes berkumur Dengan Air Rebusan Daun Sirih Dan Formula protector citrus mint

\begin{tabular}{|c|c|c|}
\hline 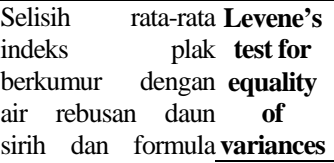 & $\begin{array}{l}\text { t-Test for equality of } \\
\text { means }\end{array}$ & $95 \%$ \\
\hline protector citrus mint $\bar{f} \quad$ Sig & DF & ver Upper \\
\hline
\end{tabular}

Dari tabel diatas diketahui bahwa hasil uji t-Test independent yang dilakukan berdasarkan Levene's Test for equality of variances diperoleh nilai f hrtung 0,73 dengan probabilitas 0,40 . Oleh karena $\mathrm{p}<0,05$ yaitu 0,012 menunjukkan bahwa Ho ditotak. Sehingga dapat disimpulkan bahwa ada perbedaan antara berkumur dengan air putih dan. formula protector citrus mint.

\section{Pembahasan}

Penelitian ini mengambil sampel sebanyak 45 siswa/i kelas IV SD Negeri No.066428 Medan Tuntungan yang dibagi dalam 3 kelompok. Kelompok pertama berkumur dengan air putih, kelompok kedua berkumur denga air rebusan daun sirih dan kelompok yang ketiga berkumut dengan formula protector citrus mint. Dalam penelitian ini dilakukan replikasi sebanyak 3 kali untuk masing-masing sampel sehingga pemeriksaan diiakukan sebanyak 135 kali. Dari hasil penelitian awal yang telah dilakukan maka diketahui bahwa banyak siswa yang memiliki indeks plak dengan criteria buruk yang berarti rendahnya tingkat kebersihan gigi dan mulut.

Berdasarkan hasil pemeriksaan awal sebelum berkumur yang telah dilakukan terhadap seluruh sampel dapat diketahui bahwa selurun sampel (100\%) memifiki kriteria indeks plak buruk namun sesudah berkumur dengan asr rebusan daun sirih diperoleh pemeriksaan indeks plak berubah dimana terdapat 55,56 \% pemeriksaan indeks plak dengan criteria baik dan $44,44 \%$ pemeriksaan indeks plak dengan criteria sedang, dengan nilai indeks plak rata-rata 0,96. Sedangkan untuk pemeriksaan sampel yang berkumur dengan formula protector citrus mint menunjukkan bahwa seluruh siswa memiliki indeks plak dengan criteria baik (100\%) dengan indeks plak rata-rata 0,77 dan berkumur dengan air putih, kriteria indeks plak berubah dimana 33,33 \% diperoleh pemeriksaan indeks plak dengan kriteria baik dan 66,7 \% diperoleh pemeriksaan indeks plak dengan kriteria sedang, dengan nilai rata-rata indeks plak 1,10.

Dari hasil penelitian uji t-Test dependent,ketiga variabel tersebut didapatkan hasil bahwa $\mathrm{p}<0,05$ atau $0,000<0,05$ sehingga Ho ditolak. Hal ini menunjukkan bahwa ketiga bahan kumur ini berpengaruh terhadap penurunan indeks plak.
Untuk mengetahui apakah ada perbedaan selisih indeks plak rata-rata antara berkumur dengan air putih, air rebusan daun sirih dan fonnula protector citrus mint terhadap penurunan indeks plak, maka dtlakukan uji t-Test independent. Melalui pengtiitungan uji t-Test independent yang telah dilakukan dengan program computer, dengan melihat dari nilai equal variences assumed antara berkumur dengan air putih dengan air rebusan dan sirih dapat diketahui bahwa nilai probabilitas 0,14. Oleh karena $\mathrm{p}<$ 0,05 yaitu 0,005 menunjukkan bahwa Ho ditolak. Sehingga dapat disimpulkan bahwa ada perbedaan antara berkumur dengan air putih dan air rebsan daun sirih, dimana berkumur dengan air rebusan daun sirih lebih efekif dibandingkan berkumur dengan air putih., hal ini terlihat dari selisih rata-rata indeks plak sebelum dan sesudah berkumur dengan air rebusan daun sirih ( 1,33 ) lebih tinggi dibandingkan dengan selisih indeks plak ratarata sebelum dan sesudah berkumur dengan air putih $(1,20)$.

Dari hasil uji t-Test independent antara berkumur dengan air putih dan formula protector citrus mint dapat kita ketahui bahwa probabilitas 0,26. Oleh karena $\mathrm{p}<0,05$ yaitu 0,000 menunjukkan bahwa Ho ditolak. Sehingga dapat disimpulkan bahwa ada perbedaan antara berkumur dengan air putih dan formula protector citrus mint, dimana berkumur dengan formula protector citrus mint lebih efekif dibandingkan berkumur dengan air putih., hal ini terlihat dari selisih rata-rata indeks plak sebelum dan sesudah berkumur dengan air rebusan daun sirih $(1,46)$ lebih tinggi dibandingkan dengan selisih indeks plak rata-rata sebelum dan sesudah berkumur dengan air putih $(1,20)$.

Dari hasil uji t-Test independent antara berkumur dengan air rebusan daun sirih dan formula protector citrus mint dapat kita ketahui bahwa probabilitas 0,40. Oleh karena $\mathrm{p}<0,05$ yaitu 0,012 menunjukkan bahwa Ho ditolak. Sehingga dapat disimpulkan bahwa ada perbedaan antara berkumur dengan air rebusan daun sirih dan. formula protector citrus mint dimana berkumur dengan formula protector citrus mint lebih efekif dibandingkan berkumur dengan air rebusan daun sirih, hal ini terlihat dari selisih rata-rata indeks plak sebelum dan sesudah berkumur dengan air rebusan daun sirih $(1,46)$ lebih tinggi dibandingkan dengan selisih indeks plak rata-rata sebelum dan sesudah berkumur dengan air rebusan daun sirih $(1,33)$.

Maka dari hasil uji t-Test independent dan berdasarkan selisih indeks plak sebelum dan sesudah berkumur dengan air putih, air rebusan daun sirih dan formula protector citrus mint dapat kita ketahui bahwa dari ketiga dari variabel tersebut formula protector citrus mint lebih efektif untuk menurunkan indeks plak. Formula protector citrus mint merupakan obat kumur yang bebas alkoho! sehingga aman digunakan. Hasil penelitian ini didukung oleh penelitian yang dilakukan penelitian lain. Menurut Profesor Robin Seymout, dotter gigi restoratif dari Newscastle University, obat kumur umumnya mengandung sejumlah bahan yang dapat menimbulkan efek merugikan pada gigi dan gusi, jika tak digunakan dengan tepat dan lebih menyarankan agar mengonsumsi obat kumur bebas alkohol. 
Dari hasil penelitian ini dapat diketahui bahwa berkumur dengan air putih, air rebusan daun sirih dan formula protector citrus mint sama-sama dapat menurunkan angka indeks plak, namun kandungan kimia yang terdapat didalam formula protector citrus mint lebih efektif untuk menurunkan indeks plak. Selain itu dapat kita ketahui bahwa kegiatan berkumur dapat menurunkan angka indeks plak. Namun fakor lain yang juga harus diperhatikan yaitu lamanya waktu berkumur, cara berkumur dan banyaknya jumlah bahan kumur.

\section{SIMPULAN DAN SARAN}

\section{A. Simpulan}

Dari hasil penelitian yang di dapat oleh peneliti maka didapat simpulan bahwa

1. Indeks plak rata-rata sebelum berkumur dengan air rebusan daun sirih adalah 2,28 yang termasuk dalam kriteria buruk. Sedangkan sesudah berkumur dengan air putih menjadi 0,96 yang termasuk dalam kriteria baik.

2. Indeks plak rata-rata sebelum berkumur dengan formula protector citrus mint adalah 2,24 yang termasuk dalam kriteria buruk. Sedangkan sesudah berkumur dengan air putih menjadi 0,77 yang termasuk dalam criteria baik.

3. Indeks plak rata-rata sebelum berkumur dengan air putih adalah 2,30 yang termasuk dalam kriteria buruk. Sedangkan sesudah berkumur dengan air putih menjadi 1,10 yang termasuk dalam kriteria sedang.

4. Persentase indeks plak sebelum berkumur air rebusan daun sirih 100\% dengan kriteria buruk dan sesudah berkumur dengan air rebusan daun sirih yaitu 66,7 dengan criteria baik serta 33,3 \% dengan criteria sedang.

5. Persentase indeks plak sebelum berkumur formula protector citrus mint $100 \%$ dengan kriteria buruk dan sesudah berkumur dengan formula protector citrus mint 100\% dengan kriteria baik.

6. Persentase indeks plak sebelum berkumur air putih $100 \%$ dengan criteria buruk dan sesudah berkumur dengan air putih yaitu 6,7 dengan kriteria baik serta 93,3\% dengan criteria sedang.

7. Hasil penghitungan uji t-Test independent didapatkan bahwa Ho dftolak yang berarti ada perbedaan antara berkumur dengan air putih, air rebusan daun sirih dan formula protector citrus mint terhadap penurunan indeks plak.

8. Berkumur dengan formula protector citrus mint lebih efektif untuk menurunkan indeks plak.

\section{B. Saran}

1. Diharapkan agar siswa/l SD Negeri No.066428 Medan Tuntungan agar lebih rajin untuk berkumur sehingga dapat meningkatkan kebersihan gigi dan mulut seperti berkumur dengan air putih, air rebusan daun sirih dan protector citrus mint serta meningkatkan intensitas berkumur sehabis makan dan setelah menyikat gigi untuk mengurangi jumlah plak pada gigi sehingga dapat mengurangi resiko terjadinya karies dan penyakit periodontal.

2. Diharapkan agar siswa/l SD Negeri No.066428 Medan Tuntungan agar lebih giat untuk menjaga kebersihan gigi dan mulut dengan cara menyikat gigi 2 kali sehari, pagi sesudah makan dan malam sebelum tidur, melakukan kontrol ke dokter gigi tiap 6 bulan sekali, mengonsumsi buah-buahan yang mengandung serat.

\section{DAFTAR PUSTAKA}

Azwar, S.1997. Metode Penetitian: Pustaka Pelajar. Yogyakarta.

Gunawan, D.,1999. Ramuan Tradisional Untuk Keharmonisan Suami Istri, :

Penebar Swadaya. Bogor. Hongini, S., Mac Aditiawarman., 2012. Kesehatan Gigi dan Mulut: Puslaka Reka

Cipta. Bandung. J.B.Visser. 1992. Patologi Gigi-Geligi: Keiainan-kelainan Jaringan Keras Gigi (terjemahan Sutatmi Suryo dan Rafiah Abyono), : Gadjah Mada University Press. Yogyakarta.

Kidd, L., Sally Joyston Bechal. Dasar-Dasar Karies : Penyakit dan Penanggulangannya (Terjemahan Narlan dan Safrida), EGC.Jakarta.

Ningrum, E., Mery Murty., 2012. Dahsyatnya Khasiat Herbal Untuk Hidup Sehat:,

Dunia Sehat. Jakarta. Narbuko.C., Abu Achmadi.1991. Metodologi Penetitian: Bumi Aksara. Semarang

Panjaitan, M.1995. Etiologi Karies Gigi dan Penyakit Periodontal'. Universitas

Pintauli, S.2008. Menuju Gigi dan Mulut Sehat: USU Press. Medan.

Sumatera Utara Press. Medan. Panjaitan, M.1995. llmu Pencegahan Karies G/gi: Universitas Sumatera Utara Press. Medan.

Tarigan, R. 1989. Kesehatan Gigi dan Mulut EGG. Medan http://id.wikipedia,orgAMiki/Sjrih diakses pada \begin{tabular}{llll}
\hline tanggal & 7 & April & 2013
\end{tabular} http://www.plantamor.com/index.php?plant=10 $\underline{06}$ diakses pada tanggal 7 April 2013

http'.//lintashambatan.wordj3ress.comftagJienis-daunsin'h/diakses pada tanggal 7 April 2013

http://repositorv.usu.ac.id/bitstream/123456789/19994/4/C hapter\%20ll.pdf diakses pada tanggal 7 April 2013

http://repositorv.usu.ac.id/bitstream/123456789/25115/4/C hapter\%20ll.pdf diakses pada tanggal 7 April 2013

http://diahmd.student.umm.ac.id/download-as-pdf/umm bloo article 35.pdf diakses pada tanggal 10 April 2013

http://www,forrnulaoralcar6.corn/portfolio-itern/protectorcool-n-fresh/diakses pada tanggal 10 April 2013 
http://repositorv.usu.ac.id/faitstream/123456789/2686e/4/C hapter\%20ll.pdf diakses pada tanggal 10 April 2013

http://cokelatbep.bloqspot.com/2012/07/tuqasmikrobiologi-makalah-tentana-Dlak.html diakses padatanggal 10 April 2013

http://svafrinaazwan.wordpress.com/2012/12/12/karvatulis-ilmiah/ diakses pada tanggal 15 April 2013 http://repositorv.ipb.ac.id/bitstream/handle/123456789/502 33/F08mrD.Ddf7seQue nce=l diakses pada tanggal 20 April 2013

http://raiasirih.blogspot.corn/jjiakses padatanggal 20 April $\underline{2013}$

http:/firstadhitvas.bloQspot.com/2011/04/fakta-obatkumur.html diakses pada tanggal 20 April 2013 